\title{
EFL Teacher's Code Switching in the Social Emotional Learning Context
}

\section{LINGGA AGUSTINA SUGANDA ${ }^{1}$, ISMAIL PETRUS ${ }^{2}$, AND ZURAIDA $^{3}$}

\begin{abstract}
The use of Indonesian, besides English, in an English as a Foreign Language (EFL) classrooms is common in Indonesia. This case study investigated the code switching used by the EFL teacher in the Social Emotional Learning (SEL) context. It was conducted in the English SEL model class at a secondary school in Indonesia. The data were collected using observation, interview, Social Emotional Competence Questionnaire (SECQ), and a SEL self-reflection tool. The results highlighted that (1) code switching is the medium of instruction used by the EFL teacher to accommodate all the teaching and learning activities in the social-emotional learning context, (2) using code switching in the EFL classroom discourse is one of the teacher social emotional competencies, and (3) code switching has a positive role to build teacher and students' social-emotional skills. Teachers who code switch can strongly support the growth of academic and social-emotional skills in EFL learning context.
\end{abstract}

\section{Keywords}

Code switching, EFL, social-emotional learning, teacher

${ }^{1}$ Faculty of Teacher Training and Education, Universitas Sriwijaya, Palembang, Indonesia: linggasuganda@fkip.unsri.ac.id

2 Faculty of Teacher Training and Education, Universitas Sriwijaya, Palembang, Indonesia: ismailpetrus@fkip.unsri.ac.id

3 Faculty of Teacher Training and Education, Universitas Sriwijaya, Palembang, Indonesia: zuraida@fkip.unsri.ac.id 


\section{IRJE | Indonesian Research Journal in Education | | Vol. 5 | No. 2| Dec |Year 2021|}

\section{Introduction}

Lack of systemic support and flexibility and limited or ineffective use of resources, including staff, make the challenges of low performing disadvantaged schools difficult to meet (OECD, 2017). There is no common understanding or definition across OECD countries of which schools are disadvantaged and performing at low levels. As each national, and even regional, context is unique, the criteria used are very diverse. For example, in Indonesia the data of the quality map from the Educational Profile of South Sumatra for junior high school level (2018) highlighted the low standards of learning process, evaluation, and learning results of the educational quality in 2016. Meanwhile, in 2017 the standard of graduate and the standard of teachers and educational staffs are two among the lowest standard quality, in which only $38 \%$ teachers are certified while $62 \%$ are not. This shows that both teachers and students are facing problem in relation to the national education quality standard. Moreover, schools nowadays are challenged to educate students coming from the multicultural and multilingual environments with much more complex social-emotional experiences. Student coming from different social and cultural background tends to struggle to accept and to be accepted by his/her surroundings.

Therefore, teachers and students nowadays need social-emotional skills to overcome these challenges. In school context it is necessary to build students' social emotional competence to increase their learning, achievement and characters as good social and emotional skills help students to gain quality of life which includes a good academic achievement during school (Wirajaya, Suganda, \& Zuraida, 2019; Alzahrani, Alharbi, \& Alodwani, 2019). Moreover, teachers' social emotional competencies may also important. According to Jennings and Greenberg (2009), these skills help teachers to reduce their stress and burnt out in the classroom context. Teachers who are skillful socially and emotionally will develop and encourage positive relationships with their students, design lessons to build students' strengths and abilities, build and implement positive characters to promote intrinsic motivation, train students to handle conflict, encourage cooperation among students, and become role models for creating a prosocial environment. Moreover, teachers also make important contribution for their students' social emotional development, which is hoped to have long lasting effects until adulthood as teachers teach their students social emotional skills which are related to their cognitive development to be focused, fully attentive, motivated, engaged, and to enjoy their work (Zins, Weissberg, Wang, \& Walberg, 2004). Therefore, to successfully implement these practices for students, teachers must also have appropriate social emotional skills.

One of the social emotional skills that teachers should have can be focused on how they handle depressing situations that can happen in classrooms and how they communicate with students effectively (Brackett et al., 2009). How teachers communicate with the students, which can be referred as teacher language, is believed to be one of the important social teaching practices for accommodating students' social, emotional, and academic skill development in the classroom (Yoder, 2014). Schools nowadays need to support appropriate culture and climate for both teachers and students in developing their social-emotional competence by implementing Social Emotional Learning (SEL) in the school. SEL ideally 


\section{IRJE | Indonesian Research Journal in Education | |Vol. 5| No. 2| Dec|Year 2021|}

takes place in schools that collaborate actively with family and community environments to support and provide chances for students to develop and apply these social and emotional competencies.

The Collaborative for Academic, Social, and Emotional Learning (CASEL), a non-profit organization that shares knowledge of highly qualified evidence based SEL, has identified five important sets of interconnected cognitive, affective, and behavioral competencies or the types of social and emotional skills for students from preschool to secondary school to develop (Durlak, Weissberg, Dymnicki, Taylor, \& Schellinger, 2011). These five skills include the ability to understand feelings and have self-confidence (self-awareness); respect and understand others, including respect the differences between people (social awareness); manage emotions and be able to set goals and stick to them (self-management); choose wisely and thoughtfully (responsible decision making); and work together, communicate, make friends, and resolve conflicts (relationship skill).

In short, SEL involves the processes where students and adults develop fundamental social and basic competencies for identifying and managing emotions, setting and achieving positive goals, feeling and showing empathy for one another, building and keeping positive relationship with one another, and making responsible decisions. It is inevitably necessary for schools to integrate the strategies of social emotional learning into the curriculum used nowadays due to the growing awareness about the significance of social and emotional development for the beneficial effects on students and teachers' practice (Martinez, 2016). SEL programs even in short term can enhance students' self-confidence, improve their involvement in school, including their test results, and decrease behavioral problems while promoting desired behaviors (Greenberg, Domitrovich, Weissberg, \& Durlak, 2017). Moreover, teachers' belief about SEL is related to their perceived efficacy for classroom management and engagement with students (Goegan, Wagner, \& Daniels, 2017). Therefore, it is believed to be necessary to have a well-planned and well-implemented SEL program in Indonesia.

Meanwhile, Indonesia is known as a multilingual country, where most of the people are bilingual, in which they use their mother tongue and Indonesian language as their second language. The third mostly used language in Indonesia is English since it is one of the compulsory subjects in the classroom discourse although it is still seen as a foreign language in Indonesian context (Suganda, Loeneto, \& Zuraida, 2018). The English teachers and their students usually use the switching and/or mixing between English, Indonesian, and the mother tongue in the classroom discourse. This presents the fact that the use of code switching occurs as a natural phenomenon in the English as a Foreign Language (EFL) classroom discourses in Indonesia (Suganda et al., 2018). Code switching refers to "the mixing, by bilinguals (or multilinguals), of two or more languages in discourse, often with no change of interlocutor or topic" (Poplack, 2001, p. 2062). Thomason (2001, p. 262) argued that code switching is "the use material from two (or more) languages by a single speaker with the same people in the same conversation that includes both switches from one language to another at sentence boundaries (intersentential switching) and switches within a single sentence (intrasentential switching). The latter is sometimes called code mixing." Code switching and code mixing are generally defined as the alternating use of two languages and have often been used vice versa (Anastassiou \& Andreou, 2017). Therefore, in this study the 


\section{IRJE | Indonesian Research Journal in Education | |Vol. 5| No. 2| Dec|Year 2021|}

term code switching also refers to some discourses claimed by other researchers as code mixing.

In teaching and learning context Lin (2008) defines classroom code switching as using more than two linguistic codes alternately by any of the participants in the classroom, such as teachers and students. It can be referred as "the alternate use of the first language and the target language as means of communication by foreign language teachers" (Üstünel, 2016, p. 29). In Indonesian EFL context, the use of code switching as a medium of instruction can serve as a beneficial conversational strategy to facilitate learning (Suganda et al., 2018) as Caparas and Gustilo (2017) also believe, "Allowing code-switching in class can promote greater interactivity because it widens comfort zone for students to participate more, aiding their second language learning (p. 357)". Code switching has been found to play an important role in giving positive contribution for English language teaching and learning process (Jingxia, 2010; Bhatti, Shamsudin, \& Mat Said, 2018).

The teachers' use of code switching can be related to their social-emotional competence as Yoder (2014) declares, "Teachers should use their language to encourage students' effort and work, restate what the student did and what he/she needs to do for keep improving. Teachers' language should encourage students how to monitor and regulate their own behavior, rather than just telling students how to behave," which are similar to the affective function of code switching (Muttsson \& Burenhult, 1999). The scarcity in the literature on code switching related to social emotional competence and the significance of findings that could increase the understanding of language use in relation to the social emotional skills in Indonesian educational context justify the need for this study, which aims to examine (1) the phenomenon of code switching used by the EFL teacher in the EFL model classroom that implemented SEL strategies and (2) how it relates to building the teacher and students' social emotional competencies.

\section{Literature Review}

\section{Code switching}

Code switching can be defined as "the alternation of two languages within a single discourse, sentence, or constituent" (Jamshidi \& Navehebraim 2013). It is a usual phenomenon that happens in bilingual societies in which people have the chance to use two or more languages for communicating. As those who can speak more than one language, bilinguals can switch code and use their languages as resources to find better ways to convey meaning. Bullock and Toribio (2009, p.2) point out several functions of code-switching namely, to fill linguistic gaps, express ethnic identity, and achieve special discursive aims

In the classroom of foreign language teaching, code switching refers to teachers' choice of languages, which are the foreign language being taught and the society's language (Simon, 2000, p.312). The teachers in such situation who Macaro (2005) called as bilingual teachers are usually non-native speakers of the target language, and they have the same mother tongue as their students'. Muttsson and Burenhult (1999) categorize the functions of teacher code switching as topic switch, affective functions, and repetitive functions. Topic switch usually occurs because the teacher switches the language due to the topic being 


\section{IRJE | Indonesian Research Journal in Education | | Vol. 5 | No. 2| Dec |Year 2021|}

taught, such as when teaching grammar or new knowledge to students. Affective functions happen when the teacher declares his/her emotion to form a relationship with the students. While, repetitive functions are used by the teacher to clarify the meaning of words, while emphasizing on the content for better understanding (Sert, 2005).

The act of code switching is believed as resources to scaffold students' learning in a foreign language classroom (Choi \& Leung, 2017). Many studies consistently find that using first language in foreign language classrooms is beneficial for students in terms of both cognitive and emotional development. First, it helps students to engage with complex tasks at a deeper level and with more self-regulation of learning (Anton \& Dicamilla, 1999), and it functions as a scaffold for understanding a lesson when students have limited English ability (Hall \& Cook, 2012). Second, it lowers the affective barriers of students with lacked confidence in using the foreign language and empowers them if their mother tongue is marginalized in the wider social context outside of the classroom (Canagarajah, 2013).

Mahboob and Lin (2016) even demanded to integrate students' first languages into theorization and practice of foreign language teaching. Therefore, in EFL teaching context, teachers usually switch code in class because they consider their students' not fully fledged language proficiency, and the first language is mostly conducted when teaching grammar and abstract concepts (Cheng, 2013). Code switching was found beneficial for both teachers and students in making clarification, repetition, recapitulation, and socialization (Adriosh \& Razi, 2019) to bridge the communication during teaching and learning process (Nurhamidah, Fauziati, \& Supriyadi, 2018), in which different frequency of code switching employed by teachers and students also occurs for social and pedagogical functions (Muslim, Sukiyah, \& Rahman, 2018). However, some researchers disagreed with the use of code switching in the classroom context. Macaro (2005) believed that code-switching should be banned as the EFL teaching usually aims at maximizing both the teacher's input and the students' output (target language acquisition) as well as to reduce out-dated methods like the grammar-translation method. In sociocultural context, code switching has been viewed as a sign of laziness and sloppiness, even attributed as language deficiency (Hussein, 1999; Iqbal, 2011).

\section{Social emotional learning}

Social Emotional Learning (SEL) refers to the process of integrating thoughts, feelings, and behaviors to be aware of oneself and others, make responsible decisions, and manage the behaviors of oneself and others (Elias et al., 1997). Students' ability to learn well depends not only on instruction, but also on factors such as the school climate, sense of belonging with peers, positive relationships with educators, and the feedback they receive. Therefore, schools nowadays are increasingly implementing school-wide SEL policies and curricula to foster teacher and student caring relationships, student cooperation and conflict reduction, a greater sense of school safety, and the social-emotional skills development in students, teachers, and school leaders (Greenberg et al., 2003; Zins, Weissberg, Wang, \& Walberg, 2004).

Meanwhile, teachers who play the most important role in classroom settings have a significant opportunity to influence their students' positive development using not only the 


\section{IRJE | Indonesian Research Journal in Education | |Vol. 5| No. 2| Dec|Year 2021|}

content of their instruction but also their social interactions and relationships quality with them, such as how these teachers manage the behavior in the classroom and model social and emotional processes (e.g., Hamre \& Pianta, 2001; Jennings \& Greenberg, 2009). Larasati, Suganda, and Jaya (2019) also found that teachers' social emotional competence (SEC) had a significant positive correlation and contribution to their students' learning motivation.

\section{Methodology}

This experimental case study was done in the seventh grade English class that was served as a classroom model implementing the social emotional learning (SEL) in a junior high school in South Sumatra, Indonesia. There were three main steps in the implementation of SEL strategy in the classroom model. First, students practiced 'Silent Sitting' by sitting in a relaxing posture and eyes closed, while at the same time the teacher would read a story with positive moral value to set them prepared for the lesson. Second, in the whilst activity teacher mostly used balanced teaching and collaborative learning strategies, such as asking open-ended questions, giving variety of possible answers for students to select, having students to repeat for checking their comprehension, having students to work in groups (large or small), in pairs, or individually, having role-plays and games. Third, students were asked to write reflective journal after they finished their class every week.

The three social-emotional learning strategies were integrated with the materials from the Indonesian 2013 national curriculum. The SEL strategy was implemented to enhance the students' five social emotional skills. Self-awareness and self-management were assumed to enhance from Silent Sitting and writing reflective journal because in these two activities each student was asked to work individually to calm their minds and reflect silently, so that they could comprehend their own feelings, have more confidence, and appropriately control their emotions. In addition, social awareness, responsible decision making, and relationship skills were assumed to be gained from in the collaborative learning activities where students kept interacting with their teacher and peers. They practiced social awareness by cooperating, working in groups, and taking turns. They also practiced decision-making and teamwork cooperation skills through discussion activities.

The data of this study were taken from classroom observation, students' Social Emotional Competence Questionnaire (SECQ), teacher interview, and teacher self-reflection tool developed by Yoder (2014). These instruments were analyzed qualitatively and quantitatively. The qualitative procedures were used in the data analysis from the classroom observation and interview to describe the code switching used in the classroom in relation to the social emotional competence to explain the study results. The teacher's use of code switching found during the observation was transcribed and grouped based on the use, and each extract was analyzed by associating them with the concept of social and emotional competence. The results from the interview were also transcribed and grouped. Meanwhile, the data from the questionnaire and self-reflection tool in the quantitative procedures were also used to support the qualitative analysis. They were described statistically to indicate the degree of both the students and teacher's social emotional competence. 


\section{IRJE | Indonesian Research Journal in Education | | Vol. 5 | No. 2| Dec |Year 2021|}

The English teacher (T1) recruited for this study agreed to participate and involve in the total of 16 meetings of 80 minutes implementation of the English social emotional learning strategy. She was teaching the class model using the procedure that included the three main steps explained before. The classroom observations were conducted for three times 80 minutes. The first observation was conducted in the first meeting and used to indicate the students' characteristics and attitudes before SEL strategies implementation. The second and third observations were conducted in the $8^{\text {th }}$ and $16^{\text {th }}$ meetings respectively. The results from the three observations were used to identify the code switching used by T1 during her teaching, and they were compared to distinguish any changing of attitude or behavior after experiencing SEL classroom discourse.

A semi-structured interview with T1 was used to obtain her perceptions and reasons of using code switching in relation to her own and her students' social emotional skills. The SECQ was administered to the students to identify their level of social emotional competence after using SEL strategies in the class. Meanwhile, the teacher's self-reflection tool from Self-Assessing Social and Emotional Instruction and Competencies: A Tool for Teachers (Yoder, 2014) was administered to know how T1 reflects her social and emotional skills. The issues of validity and reliability of the instruments were gained through triangulation of multiple data sources including the observations, questionnaires, interviews, and self-reflection tool.

\section{Findings}

\section{The results of the classroom observation}

The results from the classroom observations indicated that T1 used both Indonesian and English, and she mostly switched and/or mixed the two languages when communicating with students in her class.

Table 1. The frequency of the languages used by the teacher

\begin{tabular}{lllll}
\hline \multirow{2}{*}{ Languages } & \multicolumn{4}{l}{ Classroom Observations } \\
\cline { 2 - 5 } & $\mathbf{1}$ & $\mathbf{2}$ & $\mathbf{3}$ & Average \\
\hline Code Switching & 48.37 & 46.86 & 36.6 & 43.94 \\
Full Indonesian & 46.27 & 41.11 & 42.07 & 43.15 \\
Full English & 5.36 & 12.03 & 21.33 & 12.91 \\
\hline
\end{tabular}

Table 1 presents the average of a more dominant use of full Indonesian (43.15\%) and code switching (43.94\%) between English and Indonesian than the use of full English $(12.91 \%)$. T1 mostly spoke and explained in Indonesian and used English only to recall (1) the specific utterances as part of the teaching materials, (2) the vocabulary from the previous meetings, 


\section{IRJE | Indonesian Research Journal in Education | | Vol. 5| No. 2| Dec |Year 2021|}

and (3) the general everyday expressions for greetings, parting, complimenting, such as 'good afternoon', 'goodbye', 'keep quite', 'any questions?', 'thank you', and 'good job'.

Moreover, the motivational stories read by T1 in the 'Silent Sitting' session were all in Indonesian. Code switching was found mostly during the whilst-activity involving the collaborative learning strategies in the classroom. T1 used code switching for communicating with the students while they were having large or small group discussions, as well as individual exercises.

Figure 1. Functions of code switching

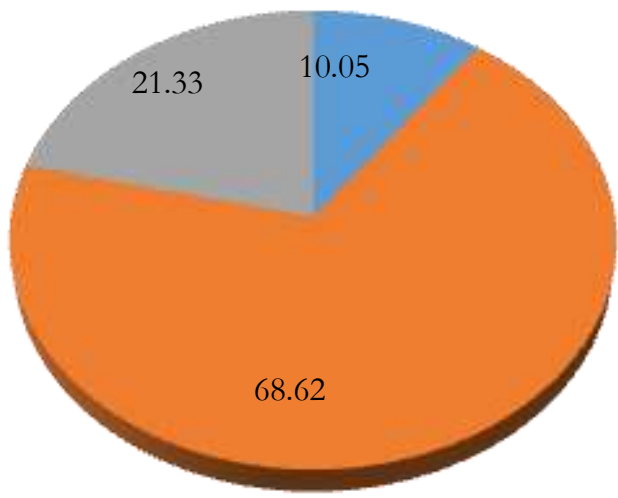

Figure 1 shows that T1 switched from English to Indonesian for topic switch $(68.62 \%)$, affective function (21.33\%), and repetitive function (10.05\%). In terms of purpose T1 mostly code switched for topic switch, which is to explain the content of the material discussed as seen in the following extract:

"My brother sama my sister its family ... anggota keluarga." [T1]

[My brother and my sister are members of family ... family member.]

Meanwhile, the other main factor T1 code switched from English to Indonesian language was the affective function. She wanted to warn and/or remind the students about their behaviors in the class. The affective function is directly related to the social-emotional competence of both the teacher and the students. Extracts 2, 3, and 4 are some examples of the affective function conducted.

"Next, S11." [T1]

[being quite because he was afraid to speak in front of the class] [S11]

"S11, tidak ada yang tidak bisa. Mengerti kata Doki tadi kan? Dia melompat. Kawannya mati, dia masih brush... Ayo cepat, S11!" [T1]

$[\mathrm{S} 11$, nothing is impossible. Did you understand what Doki said? He kept hopping. His friend died, but he kept trying... Come on, S11!] [T1]

[talking and whispering to one another] [Ss] 


\section{IRJE | Indonesian Research Journal in Education | | Vol. 5| No. 2| Dec |Year 2021|}

"Yang lain... kalau mau dihargai, hargai teman kalian. [T1]

[Class, if you want others to appreciate you, appreciate your friend. [silence] [Ss]

[talking about the bubble gum stuck on the chair in the classroom] [Ss]

Which chair? Bangkunya mana? Saya tidak mau ada yang memakan permen karet di kelas ini ya... Siapa lagi yang memakan permen karet? Permen karet itu ada bungkusnya kan? Bungkusnya itu kamu simpen di saku. Nanti kamu pake lagi buat buang permen karetnya. Bukan ditempel di bawah meja. [T1]

[Which chair? Where is the chair? I don't want any of you to eat bubble gum in the class, okay. Who else ate bubble gum? The bubble gum has its plastic wrap, right? Keep the wrap in your pocket. Use it again later to wrap the bubble gum that you want to throw away. Don't stick it on the table!] [T1]

[silent] [Ss]

The switch from English to Indonesian in Extract 2 showed T1 encouragement to S11 for trying to practice speaking in front of the class and reminding other students to appreciate S11 and not to be ignorant with their surroundings. While, in Extract 3 the code switching was used by T1 to teach and warn her students for keeping their classroom clean. In brief, the classroom observation results showed that T1 dominantly code switched between English and Indonesian for having a better communication with her students especially when delivering the material/topic of discussion. She always used general English expressions but switched and/or mixed English and Indonesian when trying to ensure about the students' comprehension on her explanations. Then, giving warning and advice is the second dominant attempt from T1 for communicating positive values to her students in which she chose to switch to Indonesian language every time she got angry, gave warning, or motivated the students.

T1 switched mostly to Indonesian language as a medium to communicate with the students. It was to give feedback and motivation. Comparing the first to the third observation, the switching between English and Indonesian occurred slightly the same in which T1 used English to express the vocabulary related to the topic and/or material and she used Indonesian language to mostly maintain their interaction, like when having simple conversation and joking. In relation to SEL context, the first to the third observations showed that T1 had become very used to the teaching procedure in the SEL classroom model. She walked around the class and communicated in Indonesian language with some switching to English to most of the students while they were discussing in groups. The students looked enthusiastic as they kept responding to T1 in both English and Indonesian and they voluntarily raised their hand to answer questions. Moreover, the warm and friendly interactions occurred among teacher-students and students-students were identified asT1 kept giving encouragement and motivation for her students. She provided feedback, motivation, and warmth smile to the students; and the students showed more positive attitudes, such as being more focused, braver to ask and talk to T1, and more motivated. It 


\section{IRJE | Indonesian Research Journal in Education | |Vol. 5| No. 2| Dec|Year 2021|}

was different from the first observation, in which the students mostly kept quiet and T1 had to keep calling their names and force them to answer questions.

\section{The results of the teacher interview and self-reflection}

The semi structured interview with T1 showed that the main reason causing her to use code switching is the students' English competence, so she used more Indonesian and code switching for topic switch to give instruction and teach the material and/or topic more effectively and efficiently. She stated that her students become more enthusiastic and have higher spirit to study compared to her previous experience where her students mostly felt burdened by English lessons because they were afraid of not understanding the English language used by their teacher. Moreover, T1 believed that Indonesian language must be used for making her students more focus and enabling them to comprehend the content of the motivational stories in the 'Silent Sitting' session because there were always moral values available from each of the story. T1 worried that this main purpose could not be gained if she chose to read the motivational stories in English. In addition, T1 also admitted that her Indonesian language was specifically used when she wanted to remind or warn her students. She wanted to make her statements more precise, so that her students would directly understand her intention. Moreover, she gave advice and reminded her students using positive utterances and avoided using high pitch and negative utterances.

Table 2. Some extracts from the interviews

\begin{tabular}{ll}
\hline Questions & Response \\
\hline $\begin{array}{l}\text { Do you code switch during the teaching } \\
\text { and learning process in the class? }\end{array}$ & Yes, I mix English and Indonesian language. \\
\hline $\begin{array}{l}\text { When do you switch from English to } \\
\text { Indonesian language? }\end{array}$ & $\begin{array}{l}\text { Explaining topic/material of the lesson } \\
\text { Clarifying words or instruction } \\
\text { Showing emotion and building relationship with } \\
\text { students (anger, happiness, and reminding students' } \\
\text { mistake) }\end{array}$ \\
$\begin{array}{ll}\text { What is the effect of your code-switching } \\
\text { use on students' comprehension on the } \\
\text { lesson? }\end{array}$ & $\begin{array}{l}\text { Students can understand the given material. When given } \\
\text { exercises, they can grasp the material faster. }\end{array}$ \\
\hline $\begin{array}{l}\text { What is the effect of your code-switching } \\
\text { use on students' characters/attitudes? }\end{array}$ & $\begin{array}{l}\text { Students become more enthusiastic and have higher } \\
\text { spirit. }\end{array}$ \\
\hline
\end{tabular}

The teacher self-reflection tool was used as the instrument to collect the data of the teacher's social-emotional competence. It consisted of a list of statements served as the teacher self-assessment test, followed by a follow-up written interview questions for gaining more information on her perception towards her social-emotional competence. 
Table 3. Teacher self-reflection on her instructional practice

\begin{tabular}{llcc}
\hline No. & Instructional Practice & Score/Total Score & Mean Score \\
\hline 1. & Youth-Centered Problem Solving & $27 / 36$ & 0.75 \\
2. & Teacher Language & $13 / 12$ & 1.08 \\
3. & Responsibility and Choice & $16 / 16$ & 1 \\
4. & Warmth and Support & $21 / 28$ & 0.75 \\
5. & Cooperative Learning/Group Learning & $19 / 20$ & 0.95 \\
6. & Group discussions & $12 / 20$ & 0.6 \\
7. & Self-Reflection and Self-Assessment & $28 / 24$ & 1.17 \\
8. & Balanced Program Practices & $15 / 20$ & 0.75 \\
9. & Encouraging Grit and Persistence & $13 / 16$ & 0.81 \\
10. & Competence Building-Modelling, Practicing, Feedback, & $18 / 20$ & 0.9 \\
& and Coaching & & 8.76 \\
\hline
\end{tabular}

The results of the self-test as presented in Table 3 showed that T1 had an average mean score of 8.76 in the implementation of SEL-based instructional exercises. She got 'Self-Reflection and Self-Assessment' and 'Teacher Language' as the highest scores because she assumed that they were related to social skills, especially in relation to the language of instruction used. For example, T1 always gave motivation to her students including in the activity of writing journal. According to T1, after experiencing SEL in the class model, the students behaved better, more polite, and more respectful. She also assumed that students had seen her as a teacher who was quite pleasant and understanding. She also believed that the use of diverse learning strategies with more communication and feedback for students would be able to facilitate the improvement in the implementation of SEL in her class.

Table 4. Teacher's social emotional competence score

\begin{tabular}{lll}
\hline Social Emotional Competence & Score/Total Score & Mean Score \\
\hline Self-awareness & $13 / 16$ & 0.81 \\
Social awareness & $8 / 16$ & 0.5 \\
Self-management & $12 / 16$ & 0.75 \\
Relationship skills & $11 / 16$ & 0.69 \\
Responsible decision making & $11 / 12$ & 0.92 \\
\hline
\end{tabular}




\section{IRJE | Indonesian Research Journal in Education | | Vol. 5 | No. 2| Dec |Year 2021|}

Table 4 shows that $\mathrm{T} 1$ obtained the highest score in responsible decision making $(\mathrm{M}=0.92)$ and self-awareness $(\mathrm{M}=0.81)$ skills, but the lowest score in self-management skill. Reflecting on the score, T1 claimed that her social-emotional skills were still not too good. She did not consistently filter out her own personal goals; and her emotional control techniques were still ineffective. T1 assumed that having better and efficient reflection on her previous learning activities could facilitate the improvement of her self-management skill. T1 also acknowledged that some of the implementation of this social emotional learning was still less optimal, especially on the practice of emotional control (silent sitting) and the large group activities because they were not regularly carried out. It happened because of the demands of the curriculum to complete the material and to conduct the conventional periodic evaluations (written tests and quizzes).

\section{The results of students' social-emotional competence questionnaire}

Table 5 showed that the mean score for the students' SEC is 83.86 with the standard deviation of 14.554 , and most of the students $(71.4 \%)$ were in moderate category. The data merely reflect the students' existing SEC during the study or when data were taken.

Table 5. The students' SEC score distribution

\begin{tabular}{cccccc}
\hline Interval & Category & Number of Students & Percentage & Mean & Std. \\
\cline { 6 - 6 } & Low & 5 & $14.3 \%$ & & \\
$72-71$ & Moderate & 25 & $71.4 \%$ & 83.86 & 14.554 \\
$98-125$ & High & 5 & $14.3 \%$ & & \\
\hline
\end{tabular}

In relation to the five types of SEC, Table 6 shows that the highest mean score was self-awareness $(\mathrm{M}=3.69)$, followed by responsible decision making $(\mathrm{M}=3.51)$, self-management $(M=3.23)$, relationship skills $(M=3.19)$, and social awareness $(M=3.13)$. Most students had higher self-awareness and responsible decision-making skills than the other three skills.

Table 6. Students' SEC overall mean score

\begin{tabular}{|c|c|}
\hline Social Emotional Competence & Mean \\
\hline Self-awareness & 3.69 \\
\hline Responsible decision making & 3.51 \\
\hline Self-management & 3.23 \\
\hline Relationship skills & 3.19 \\
\hline Social awareness & 3.13 \\
\hline
\end{tabular}




\section{IRJE | Indonesian Research Journal in Education | | Vol. 5 | No. 2| Dec |Year 2021|}

\section{Discussion}

This study indicated that the percentage of the teacher's use of full Indonesian $(43.15 \%)$ and code switching $(43.94 \%)$ is very similar or almost equal. Her focus of using the certain medium of instruction was to explain the topic or material of the lesson, to clarify her words or instruction, and to show her emotion (i.e. anger, happiness, and reminding students' mistake) and build relationship with students as Brock-Utne (2007) claims, "Students engage in meaningful conversations and build on prior knowledge through the use of a familiar language in which English as the only medium of instruction inhibits effective English learning and interaction, but using the first language to clear misunderstanding, reduce confusion and thus facilitate learning can be considered a valuable communicative and pedagogical strategy." Furthermore, these results highlighted that the teacher consciously chose which language to use during her teacher-student interaction. In relation to the social emotional competence, this study showed that the teacher possessed appropriate responsible decision making and self-awareness skills as seen in the results of her self-reflection assessment. Teachers' code-switching is one of the teacher's positive efforts because they have a special responsibility to support student motivation and learning including through the provision of warmth and engagement, optimal structure, and autonomy support (Furrer, Skinner, \& Pitzer, 2014).

Meanwhile, this study's results also showed that the teachers' second dominant reason for her code switching was affective reason, which is specifically for building a positive teacher-students relationship. To make students feel safe and comfortable with her, the teacher should build a strong relationship with the students from time to time by showing respect, listening to, talking to, and making eye contact with them during daily communication (Alzahrani, Alharbi, \& Alodwani, 2019).

Regarding to the teacher-students relationship as the aspect of a positive learning environment, code switching assists teachers to foster a better relationship with students (Moghadam, Samad, \& Shahraki, 2012) meaning that teachers can build positive relationships with individual and groups of students in diversity, communicate clearly, work together, resolve conflicts, and seek helps from one another. Bhatti et al (2018) also claim, "Teacher code-switched to maintain discipline, translate new words and build solidarity and intimate relationship with the students before, during and after the lessons" (p. 93). The affective reason of code switching is believed to be closely related to two among the five SEC, namely social awareness and relationship skills. Social awareness covered how to take perspective, empathy, respect diversity, understand social and ethical norm for behavior, and recognize family, school, and community supports. While relationship skills involved how to build relationships with various different individual and groups, communicate clearly, work cooperatively, resolve conflicts, and seek for help.

Moreover, using positive encouraging utterances and statements in the affective reason is assumed to be more effective than using high pitch and negative discouraging utterances and statements. By doing so, the teacher was also building the students' positive characters as the teacher who performs code switching is choosing certain cultural and linguistic behaviors to build social emotional competence with their students (Hollie, 2011). 


\section{IRJE | Indonesian Research Journal in Education | |Vol. 5| No. 2| Dec|Year 2021|}

A good teacher was responsible to build students social emotional competencies by giving warning and reminder to students for behaving well, and the teacher intentionally code-switched while doing them. It means that the teacher' use of code-switching leads to the teacher's own social emotional competencies that contribute in building the students' social emotional competencies, too. Therefore, the teacher's use of code switching in the classrooms is believed to play a positive role to build teacher and students' SEC within the classroom discourse.

Meanwhile, the result of the SEC questionnaire showed that the majority of the students $(71.4 \%)$ had moderate social-emotional competence. Self-awareness and responsible decision making were two among the competencies with the highest mean score meaning that most of the students were good enough in understanding and managing emotions, setting and achieving positive goals, feeling and showing empathy for others, establishing and maintaining positive relationship, and making responsible decisions. It is assumed that the students could recognize their emotions, emotional patterns, and tendencies and know how to produce and use emotions such as joy and enthusiasm to motivate learning within themselves and others, and they demonstrate prosocial values and make responsible decisions based on the assessment of factors including how their decisions might affect themselves and others (Jennings \& Greenberg, 2009). Moreover, the results also showed that students had enough competencies in self-management, relationship skills, and social awareness meaning that they had enough skills in knowing how their emotional expressions could affect their interaction with others. Therefore, they knew how to manage their emotions, behavior, and relationships with others.

Overall, these five skills are believed to help students in creating a conducive and effective learning English environment. This shows that the social emotional learning classroom model worked well to provide better environment for students to enrich their social emotional competence including for developing understanding and empathy (Husaj, 2016) and coping with difficulties more successfully by improving skills and mindset (Yeager, 2017). Furthermore, the use of code switching in the classroom discourse can be considered as one of the teacher's social emotional competencies because T1 recognized her tendencies to code switched while interacting with her students as the high 'Self-Reflection and Self-Assessment' and 'Teacher Language' scores in her self-reflection assessment result showed that she knew how to reflect and assess her social skills including the skills related to the language of instruction she used. She was aware that her use of code switching can affect her interaction with the students, including in managing the behavior and relationships among them as 'teachers' social and emotional skills influence student behavior, engagement, attachment to school, and academic performance, and teachers who are skilled at regulating their emotions report less burnout and more positive affect when teaching" (Durlak, et al, 2011).

\section{Conclusion}

This study indicated that code switching is the medium of instruction used by teacher to accommodate all the teaching and learning activities in the social-emotional learning context. Using code switching during the teaching and learning process is one of teachers' 


\section{IRJE | Indonesian Research Journal in Education | |Vol. 5| No. 2| Dec|Year 2021|}

social emotional competencies. Building a positive and warm relationship with students is an important function of code switching made consciously by the teacher in the social-emotional learning context to build the students 'social emotional skills.

Moreover, this study also provides support that teachers' use of code switching in the social emotional learning contexts can be a promising strategy to promote students' social emotional, behavioral, academic outcomes, and positive classroom climate. Academic and social emotional learning has become the new standard as the basics in education that students should obtain during their school experiences nowadays. Caring relationships and challenging but warm classroom and/or school environment are the foundation of an effective, sustainable academic and social-emotional learning. Therefore, the switch between Indonesian and English in the EFL classrooms plays a positive role to build the social emotional competencies of teachers and students. The teachers conducting code switching can be particularly supportive for the growth of academic and social-emotional skills in EFL context. However, it should be part of a deliberate and balanced approach, in which teachers design and plan clearly for when to use each language and what specific goals they want to obtain. When using code switching in the context of SEL, teachers insist on having a better communication, reminding, and motivating the students to have good SEC. However, this initial study is still incomplete and needs to be extended to understand how it might give impact on the students 'social-emotional competencies if conducted in regular classes that do not implement Social Emotional Learning strategy. These are also essential next steps to pursue if we think of the benefits in implementing social-emotional learning strategy for supporting students' positive learning in terms of academic and characters/personalities. Therefore, it is suggested for other researchers to conduct more qualitative and quantitative studies on this topic.

\section{Disclosure statement}

The authors declare that there is no potential conflict of interest in relation to the publication of this article.

\section{Acknowledgments}

The authors would like to acknowledge the assistance and cooperation from the English teacher, students, and staffs in the school participating in this study starting from the process of pre-survey to the data collection; and the financial support (Sriwijaya University Science, Technology, and Arts 2019 Grant) from Sriwijaya University Research and Public Service Institution.

\section{References}

Adriosh, M., \& Razi, O. (2019). Teacher's code switching in EFL undergraduate classroom in Libya: Functions and perceptions. SAGE Open, 1-11.

Alzahrani, M., Alharbi, M., \& Alodwani, A. (2019). The effect of social-emotional competence on children academic achievement and behavioral development. International Education Studies, 12(12), 141-149. 


\section{IRJE | Indonesian Research Journal in Education | | Vol. 5 | No. 2| Dec |Year 2021|}

Anastassiou, F., \& Andreou, G. (2017). Factors associated with the code mixing and code switching of multilingual children: An overview. International Journal of Linguistics, Literature and Culture, 4(3), 13-26.

Anton, M., \& Dicamilla, F. J. (1999). Socio-cognitive functions of L1 collaborative interaction in the L2 classroom. The Modern Language Journal, 83(2), 233-247.

Bhatti, A., Shamsudin, S., \& Binti Mat Said, S. (2018). Code-switching: A useful foreign language teaching tool in EFL classrooms. English Language Teaching, 11(6), 93-101.

Bullock, B. E., \& Toribio, A. J. (2009). Themes in the study of code-switching. In B. E. Bullock \& A. J. Toribio (Eds.). The Cambridge handbook of linguistic code-switching (pp. 1-17). Cambridge: Cambridge University Press.

Brackett, M. A., Patti, J., Stern, R., Rivers, S. E., Elbertson, N. A., Chisholm, C., et al. (2009). A sustainable, skill-based approach to building emotionally literate schools. In M. Hughes, H. I. Thompson, \& J. B. Terrell (Eds.), Handbook for developing emotional and social intelligence: Best practices, case studies, and strategies (pp. 329-358). San Francisco, CA: Pfeiffer.

Brock-Utne, B. (2007). Language of instruction and student performance: new insights from research in Tanzania and South Africa. International Review of Education, 53, 509-530.

Canagarajah, A. S. (2013). Translingual practice: Global Englishes and cosmopolitan relations. New York, NY: Routledge.

Caparas, P., \& Gustil o, L. (2017). Communicative aspects of multilingual code switching in computer-mediated communication. Indonesian Journal of Applied Linguistics, 7(2), 349-359.

Cheng, X. (2013).Research on Chinese college English teachers' classroom code-switching: Beliefs and attitudes. Journal of Language Teaching and Research, 4(6), 1277-1284.

Choi, T.H., \& Leung, C. (2017). Uses of first and foreign languages as learning resources in a foreign language classroom. The Journal of Asia TEFL, 14(4), 587-604.

Durlak, J. A., Weissberg, R. P., Dymnicki, A. B., Taylor, R. D., \& Schellinger, K. B. (2011). The impact of enhancing students' social and emotional learning: A meta-analysis of school-based universal interventions. Child Development, 82, 405-432.

Elias, M. J., Zins, J. E., Weissberg, R. P., Frey, K. S., Greenberg, M. T., Haynes, N. M., . . . Shriver, T. P. (1997). Promoting social and emotional learning: Guidelines for educators. Alexandria, VA: Association for Supervision and Curriculum Development.

Furrer, C. J., Skinner, E. A., \& Pitzer, J. R. (2014). The Influence of Teacher and Peer Relationships on Students' Classroom Engagement and Everyday Motivational Resilience. National Society for the Study of Education, 113(1), 101-123.

Greenberg, M. T., Weissberg, R. P., O'Brien, M. U., Zins, J. E., Fredericks, L., Resnik, H., \& Elias, M. J. (2003). Enhancing school-based prevention and youth development through coordinated social, emotional, and academic learning. American Psychologist, $58,466-474$.

Goegan, L. D., Wagner, A. K., \& Daniels, L. M. (2017). Pre-service and practicing teachers' commitment to and comfort with social emotional learning. Alberta Journal of Educational Research, 63(3), 267-285. 


\section{IRJE | Indonesian Research Journal in Education | | Vol. 5 | No. 2| Dec |Year 2021|}

Greenberg, M. T., Domitrovich, C., Weissberg, R. P., \& Durlak, J. A. (2017). Social and emotional learning as a public health approach to education. The Future of Children, 27(1), 13-32.

Hall, G., \& Cook, G. (2012). Own language use in language teaching and learning. Language Teaching, 45(3), 271-308.

Hamre, B. K., \& Pianta, R. C. (2001). Early teacher-child relationships and the trajectory of children's school outcomes through eighth grade. Child Development, 72, 625-638.

Hollie, S. (2011). Culturally and linguistically responsive teaching and learning: Classroom practices for student success. Huntington Beach, CA: Shell Educational Publising, Inc.

Husaj, S. (2016). Social emotional learning (SEL). European Journal of Multidisciplinary Studies, 1(3), 168-171.

Hussein, R. F. (1999). Code-alteration among Arab college students. World Englishes, 18(2), 281-289.

Iqbal, L. (2011). Linguistic features of code-switching: A study of Urdu/English bilingual teachers' classroom interactions. International Journal of Humanities Social Science, 1(4), 188-194.

Jamshidi, A., \& Navehebrahim, M. (2013). Learners' use of code switching in the English as a foreign language classroom. Australian Journal of Basic and Applied Sciences, 7(1), 186-190.

Jennings, P. A., \& Greenberg, M. T. (2009). The prosocial classroom: Teacher social and emotional competence in relation to student and classroom outcomes. Review of Educational Research, 79, 491-525.

Jingxia, L. (2010). Teachers' code-switching to the L1 in EFL classroom. The Open Applied Linguistics Journal, 3(10), 10-23.

Larasati, A., Suganda, L. A., Jaya, H. P. (2019). Indonesian English teachers' social-emotional competence and students' English learning motivation. Indonesian Journal of English Language Teaching and Applied Linguistics, 4(1), 83-94.

Lin A.M.Y. (2008). Code-switching in the classroom: Research paradigms and approaches. In N. H. Hornberger (Ed), Encyclopedia of Language and Education (pp. 3464-3477). Boston, MA: Springer.

Macaro, E. (2005). Code-switching in the L2 classroom: A communication and learning strategy. In E. Llurda (Eds.), Non-native Language Teachers: Perceptions, Challengers and Contributions to the Profession (pp. 63-84). New York, NY: Spring Science.

Mahboob, A., \& Lin, A. (2016). Using local languages in English language classrooms. In H. Widodo \& W. Renandya (Eds.), English language teaching today: Building a closer link between theory and practice (pp. 25-40). New York, NY: Springer International.

Martinez, L. (2016). Teachers' Voices on social emotional learning: Identifying the conditions that make implementation possible. The International Journal of Emotional Education, 8(2),6-24.

Moghadam, S. H., Samad, A. A., \& Shahraki, E. R. (2012). Code-Switching as a medium of instruction in an EFL classroom. Theory and Practice in Language Studies, 2, 2219-2225.

Muslim, Sukiyah, H., \& Rahman, A. (2018). A study of teachers and students' code switching in EFL classroom setting. Journal of English Language Teaching, 5(1), 21-33. 


\section{IRJE | Indonesian Research Journal in Education | | Vol. 5 | No. 2| Dec |Year 2021|}

Muttsson, A. F., \& Burenhult, N. (1999). Code switching in second language teaching of French. Working Papers, 47, 59-72.

Nurhamidah, Fauziati, E., \& Supriyadi, S. (2018). Code-switching in EFL Classroom: Is it good or bad? Journal of English Education, 3(2), 78-88.

Poplack, S. (2001). Code Switching: Linguistic. In N. Smelser\&P. Baltes (eds.), International Encyclopedia of the Social \& Behavioral Sciences (pp. 2062-2065). Elsevier Science Ltd.

Sert, O. (2005). The function of code switching in ELT classrooms. The Internet TESL Journal, 11.

Simon, D. (2000). Towards a new understanding of code-switching in the foreign language classroom.In R. Jacobson (Eds.), Code-switching Worldwide II (pp. 311-342). Berlin: Mouton de Gruyter.

Suganda, L. A., Loeneto, B. A., \& Zuraida. (2018). Teachers' Use of Code Switching in Indonesian Context. Script Journal: Journal of Linguistics and English Teaching, 3(2), 111126.

Thomason, S. G. (2001). Language contact: An introduction. Edinburgh: Edinburgh University Press.

Üstünel, E. (2016). EFL Classroom code-switching. London: Palgrave Macmillan.

Wirajaya, G., \& Suganda, L. A., \& Zuraida. (2019). Indonesian students 'social -emotional competencies and their English academic achievement. Journal of Education and Learning, 13(2), 163-169.

Yeager, D. (2017). Social-emotional learning programs for adolescents. The Future of Children, 27(1), 31-52.

Yoder, N. (2014). Self-Assessing Social and Emotional Instruction and Competencies: A Tool for Teachers. Washington: American Institutes for Research.

Zins, J. E., Weissberg, R. P., Wang, M. C., \& Walberg, H. J. (Eds.). (2004). Building academic success on social and emotional learning: What does the research say? New York, NY: Teachers College Press.

\section{Biographical Notes}

LINGGA AGUSTINA SUGANDA is a faculty member of English Education Study Program, Faculty of Teacher Training and Education, Universitas Sriwijaya.

ISMAIL PETRUS is an assistant professor in English Education Study Program, Faculty of Teacher Training and Education, Universitas Sriwijaya.

ZURAIDA is an assistant professor in English Education Study Program, Faculty of Teacher Training and Education, Universitas Sriwijaya. 